\title{
EPIDEMIOLOGICAL INVESTIGATION OF SCHISTOSOMIASIS MANSONI IN MUNICIPALITIES IN THE MARANHÃO STATE, BRAZIL
}

\author{
1, ${ }^{*}$ Maria de Fátima Castro Mendes; ${ }^{2}$ Diogo Marcelo Lima Ribeiro; ${ }^{2}$ Bruna de Oliveira de Melo; ${ }^{3}$ Maria \\ Rosa Quaresma Bomfim
}

${ }^{1}$ Post Graduate student in Biotechnology and Biodiversity in the BIONORTE network, São Luis, Maranhão, Brazil. ${ }^{2}$ Graduate student in Biomedicine in the Ceuma University, São Luis, Maranhão, Brazil. ${ }^{3}$ Professor / Adjunct Coordinator of the Postgraduate Program (Master in Parasitary Biology) in the CEUMA University, São Luis, Maranhão, Brazil.

${ }^{*}$ Corresponding author: fcmendes02@hotmail.com

Received: Sep. 07, 2017 - Accepted: Oct. 12, 2017

DOI: http://dx.doi.org/10.22615/2526-1746-jgm-2.3-6851

\begin{abstract}
Schistosomiasis is a serious parasitic infectious disease, one of the most important waterborne diseases, which is closely related to poverty, lack of health education and basic sanitation. It is a public health problem in Brazil, presenting endemic in some municipalities in the Maranhão State. In this way, this study aimed to evaluate the research profile of schistosomiasis mansoni in some endemic municipalities in the Maranhão State. A descriptive, retrospective and quantitative study was carried out with data obtained in "Programa de Controle da Esquistossomose (PCE) - MA" (Program for Schistosomiasis Control) between 2005 and 2015. We evaluated 42, 40 and 25 municipalities in the years 2005, 2010 and 2015, respectively. In 2005 the population evaluated was 184787, in 2010162220 and in 2015 they were only 48484. The highest number of people evaluated in the year 2015 was in São Luís (8068) and the lowest was in Tutoia (83). The municipalities of Bacurituba, Guimarães, Guimaraes, Mirinzal, Paulino Neves and São João Batista presented a survey coverage of schistosomiasis major in the year 2015, compared to 2005 and 2010. Schistosomiasis remains a public health problem in the Maranhão State, however, its scope of research is still low, taking into account the number of endemic municipalities, sites susceptible to infection and the number of people examined.
\end{abstract}

Key words: Schistosomiasis; Schistosoma mansoni; Maranhão. 


\section{INTRODUCTION}

Schistosomiasis is a public health problem, endemic in several countries, including Brazil. The disease affects thousands of people leading to a high number of deaths. According to the World Health Organization, it ranks second among the parasitic diseases that infect man, leaving behind only malaria (BRAZIL, Ministério da Saúde, 2014).

Around 200-300 million people in the world are infected with one of the five species of Schistosoma, and 779 million are at risk of being affected by the parasite (WHO, 2011). In Brazil, schistosomiasis is caused by Schistosoma mansoni, with man being its definitive host and freshwater snails (Biomphalaria), its intermediate hosts. In endemic areas, people use rivers inhabited by snails infected by Schistosoma mansoni for fishing, bathing, laundry and dishwashing, thus becoming susceptible to infection (Couto, 2005). The transmission occurs through the contact of the man with the worm in contaminated waters of rivers, streams, irrigation valleys and ponds, or through poor sanitation conditions (BRAZIL, Ministério da Saúde, 2010).

Schistosomiasis mansoni or "barriga d'água" is an infectious disease related to poverty and low socioeconomic development (ROCHA, et al., 2016). It is found throughout the brazilian territory, however, the populations of Northeast and Southeast regions are the most affected. The states with the highest incidence and prevalence of the disease are Alagoas, Sergipe, Bahia and Pernambuco. It is estimated that 1.5 million people live in areas at risk for contracting the parasite (BRAZIL, Ministério da Saúde, 2014).
In municipalities with records of the disease, the prevalence and intensity of infection are subject to variations related to practices culturally established by economic, leisure or domestic activities, which are distinct in each locality. The control measures should contemplate all these by minors, if they aim for efficiency in their actions (BARBOSA and BARBOSA, 1998).

In Maranhão, a schistosomiasis has an ancient origin. Cases of the disease were recorded in the 1920s in the municipalities of São Luís and Cururupu (FERREIRA et al., 1998). The municipalities of the Baixada Maranhense Microregion are the places with the highest prevalence of the disease in the State, probably due to the proximity and the greater contact with water, which favors the risk of infection by Shistosoma mansoni (BRAZIL, Ministério da Saúde, 2014; CANTANHEDE et al., 2014). Due to the severity of the disease and its endemicity in some municipalities of the State of Maranhão, the present study aimed to evaluate the profile of schistosomiasis research in some municipalities considered endemic in Maranhão from 2005 to 2015.

\section{MATERIAL AND METHODS}

This is a descriptive, retrospective and quantitative research based on secondary data from the Program for Schistosomiasis Control "Programa de Controle da Esquistossomose (PCE) - MA", obtained from the source MS/SVS/GT-PCE. The information was presented to the endemic municipalities of Maranhão during the periods in which surveys were conducted by PCE (2005, 2010 and 2015), being evaluated 42, 40 and 25 
municipalities, respectively. Data collection was based on the investigation of disease in the population (working population) of some municipalities in the State of Maranhão. The data were plotted in a spreadsheet of the program Microsoft Office Excel ${ }^{\circledR}$, analyzed descriptively and expressed in absolute and relative frequencies.

\section{RESULTS AND DISCUSSION}

Schistosomiasis in the State of Maranhão is endemic in 20 and focal in 29 of 217 municipalities (BRASIL, Ministério da Saúde, 2011). In the present study, secondary data from MS/SVS/GT-PCE were used on the populations worked for schistosomiasis in the years 2005, 2010 and 2015, totaling 184787, 162220 and 48484, respectively (Graphics 1, 2 and 3 ).

Most of the municipalities investigated are part of the Northern Mesoregion of Maranhão, which is constituted by the union of the capital São Luís with sixty municipalities, grouped in six Microregions (Urban Agglomeration of São Luís, Baixada Maranhense, Itapecuru Mirim, Lençóis Maranhenses, Litoral Ocidental Maranhense e
Rosário) (IBGE, 2016). According to data from the Ministry of Health, schistosomiasis in Maranhão is endemic in 20 and focal in 29 of the 217 existing municipalities. The Baixada Maranhense Microregion presents the oldest and most prevalent focus of this parasitosis (BRASIL, Ministério da Saúde, 2011).

Comparing Graphics 1, 2 and 3, it was verified that of the forty-seven municipalities studied the highest numbers of investigations of schistosomiasis in the three periods studied were carried out in the municipalities of São Luis (34254 / 4174 / 8068) and São Bento (7814 / 9767 / 5663), totaling together, a quantitative of 69640 investigations. While the municipality with the lowest number in the same period, with 83 people worked was Tutoia. Some municipalities such as Anajatuba, Centro novo do Maranhão, Itapecuru Mirim, Rosario, Santa Helena, Santa Rita, Senador La Rocque and Turilândia were studied only in 2005, others only in 2010, such as Alcântara, Godofredo Viana and Maracaçumé. 


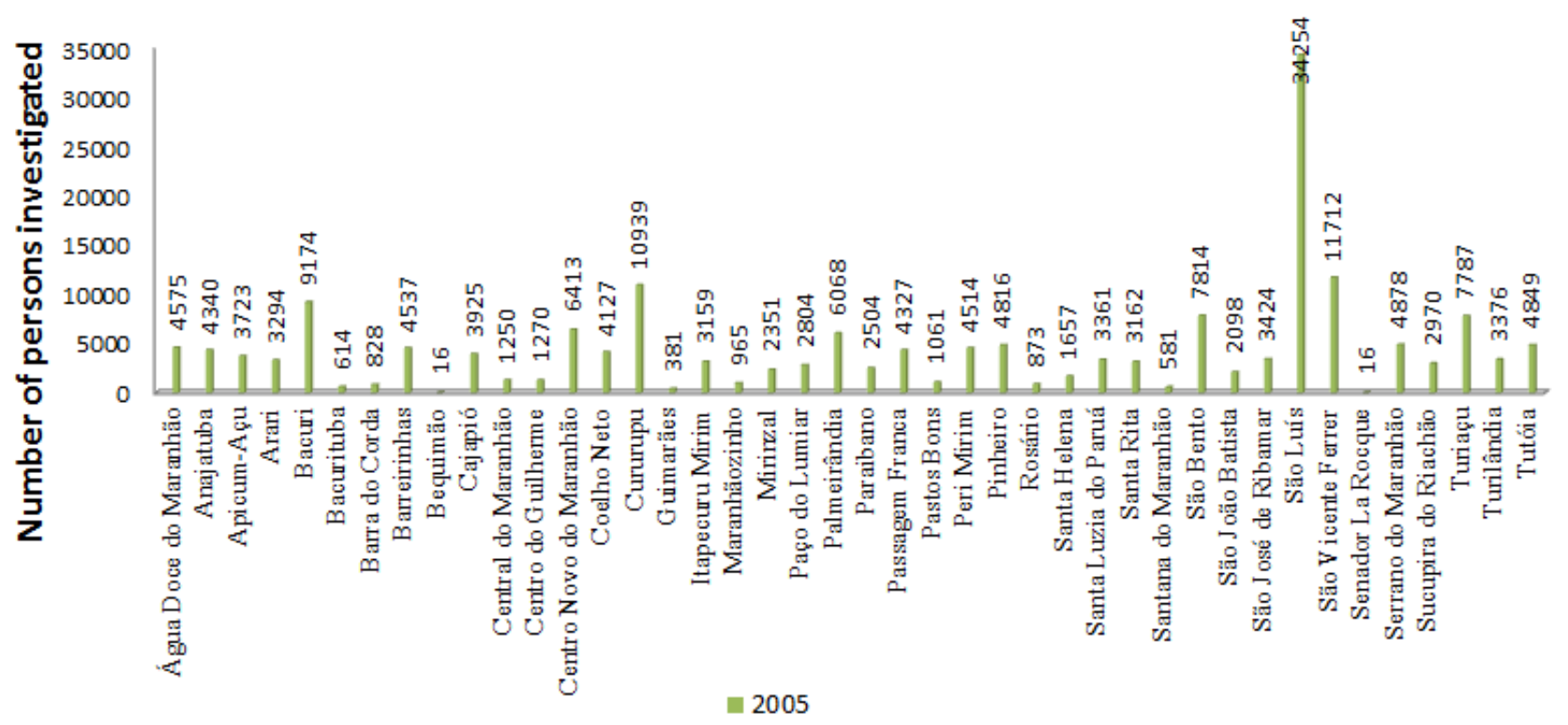

Graphic 1. Investigation of schistosomiasis in some municipalities located in Maranhão State in the year 2005.

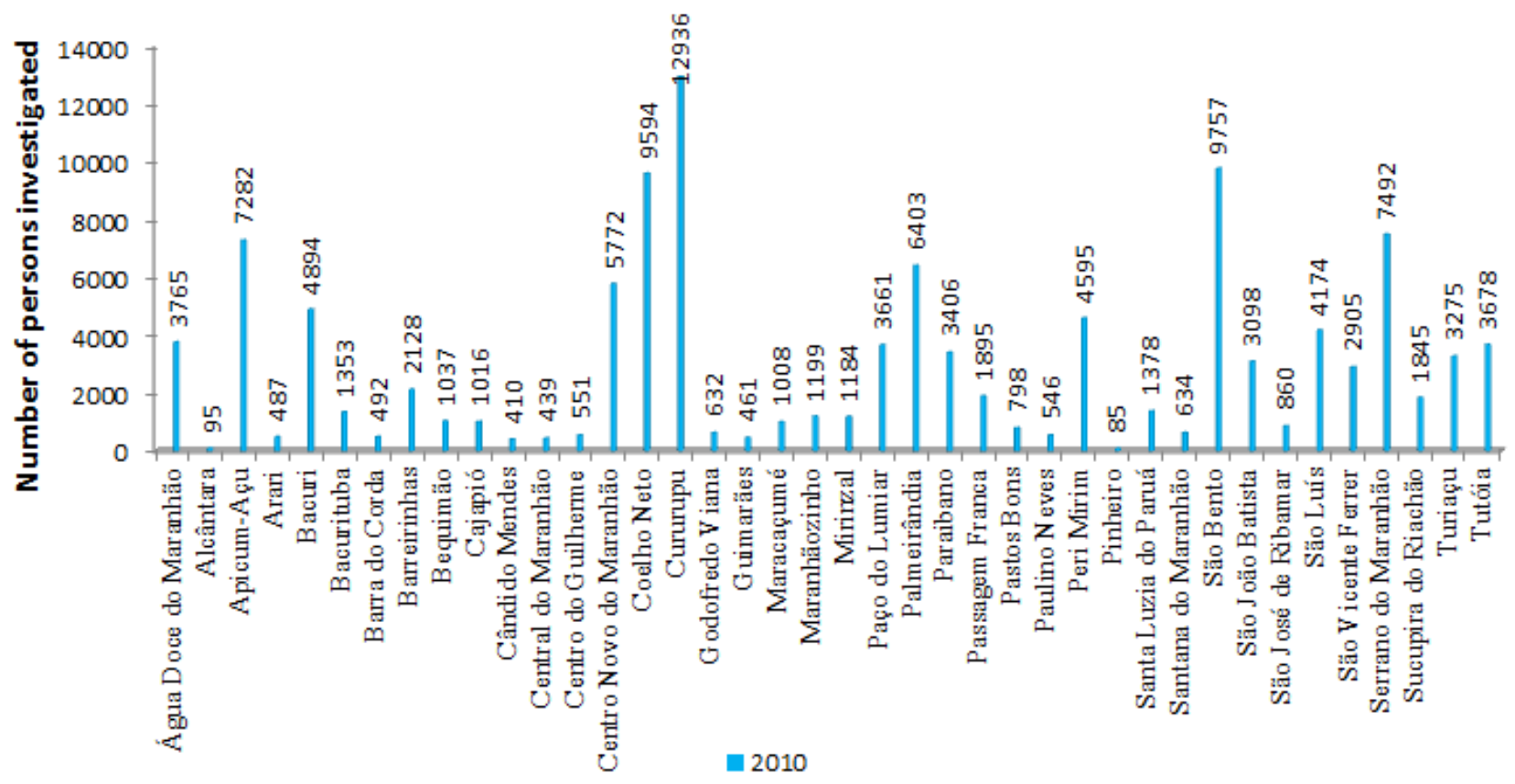

Graphic 2. Investigation of schistosomiasis in some municipalities located in Maranhão State in the year 2010. 


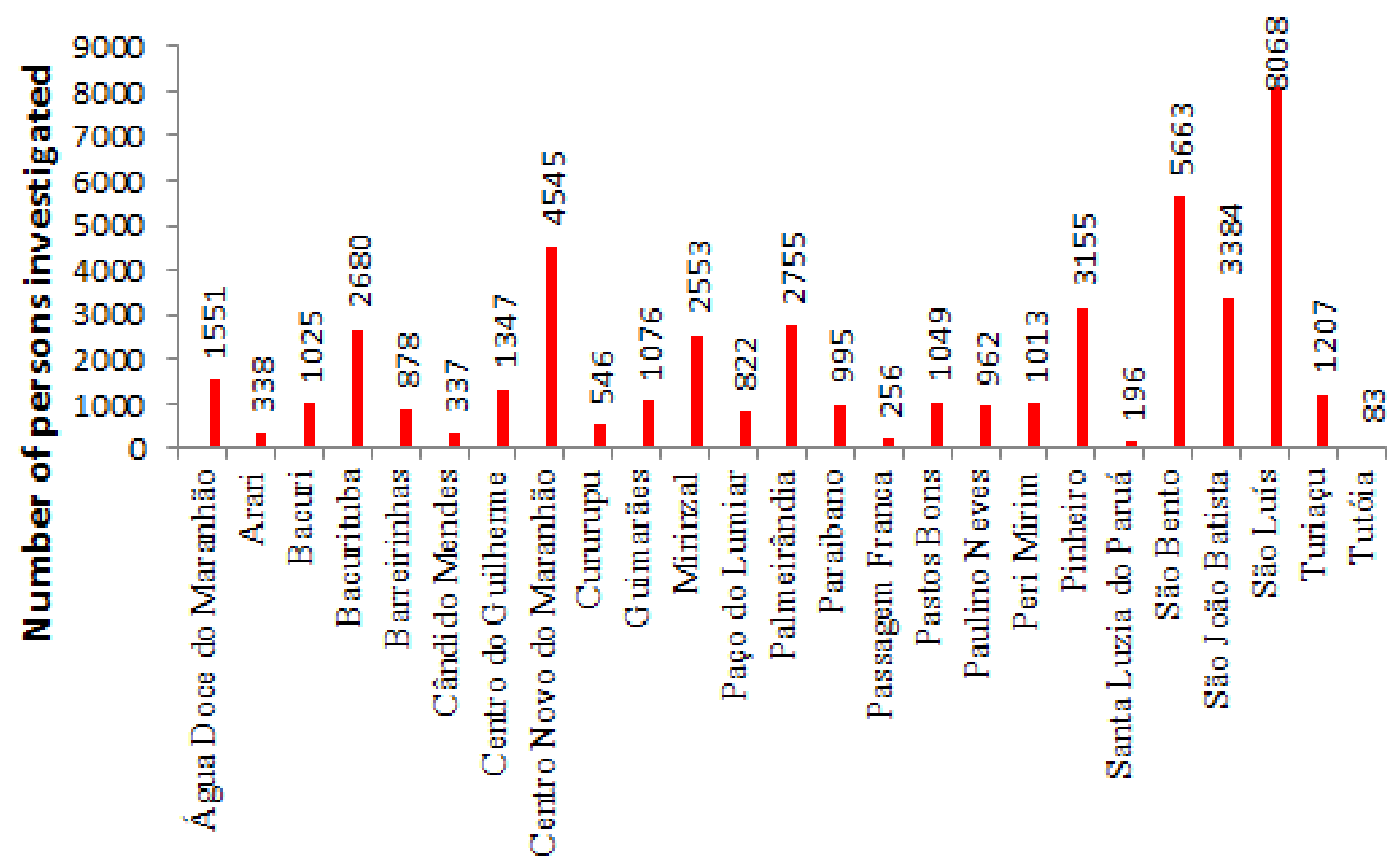

2015

Graphic 3. Investigation of schistosomiasis in some municipalities located in Maranhão State in the year 2015.

The municipalities of Bacurituba, Guilherme, Guimarães, Mirinzal and São João Batista presented a survey coverage of schistosomiasis major in the year 2015 compared to 2005 and 2010, totaling together a quantitative of 10494 investigations. Representing respectively: $48 \%, 10 \%, 9 \%, 17 \%, 17 \%$ of the population of municipality that was investigated. It is worth noting that the municipality of Bacurituba had one of the lowest Municipal Human Development Index (MHDI) in Maranhão, 0.537 in 2010. The cities mentioned are located between the North and West Mesoregion of Maranhão, where there is a higher prevalence of positive cases.

In the year 2015, the municipalities of Bacurituba, Centro Novo do Maranhão, Mirinzal and São João Batista presented one of the largest research coverage, representing respectively, $48 \%, 21 \%, 17 \%$ and $17 \%$ of the population of municipality. These municipalities presented a range $<5 \%$ of positivity of schistosomiasis. Bacurituba, Mirinzal and São João Batista are located in the Northern Mesoregion and Centro Novo do Maranhão in West Mesoregion. The two municipalities with the lowest percentage of population surveyed were Tutoia $(0.14 \%)$ and Paço do Lumiar (0.7\%). Tutoia is considered an endemic area, because it is located in Lençois Maranhenses Microregion, in North of Maranhão, composed of beaches, mangroves, dunes, lakes and rivers, with a low number of investigations. Taking into account that among the municipalities studied, Paço do Lumiar is the second municipality with the highest MHDI, its coverage of research was also low.

According to the Ministry of Health the number of positive cases of schistosomiasis 
recorded in municipalities of Maranhão between 2000 and 2015 was 72538 cases. In this same period, the highest number occurred in 2005, with 8946 and the lowest in 2015, with 1013 cases (BRAZIL, Ministério da Saúde, 2014). Probably, this decrease in number of positive cases was reflected by the lower coverage of research in municipalities and not by an effective control of schistosomiasis.

In 2010, the MHDI of São Luis was 0.768 (IBGE, 2016). NASCIMENTO (2011), in an epidemiological analysis of schistosomiasis in risk areas in São Luís, described that approximately $83 \%$ of the families came from endemic areas (Baixada Maranhense) and state outbreaks, $60 \%$ of them traveling and receiving visits from relatives in these areas. $27 \%$ of these families have 2 or more people contaminated, $60 \%$ do not know how to get schistosomiasis, $31 \%$ do not know the snail and $41 \%$ of families, whose individuals are constantly in contact with contaminated water, had more than one case of the disease.

The numbers studied represent a need for basic sanitation, health education, treatment and control of patients. There is also a need for the commitment of the public power, since the slogan "to eradicate", does not exist as argument, since the decrease in number of working population, which may have been reflected in the decrease of positive cases of the disease.

\section{CONCLUSION}

Although Maranhão has several endemic municipalities and sites at risk of infection by schistosomiasis mansoni, its research coverage is still low. The extinction of the disease and focus of contamination is still a problem to be faced. To eradicate the disease, it is necessary to correct the evolutionary cycle of worm by means of basic sanitation measures, treatment of infected and changes in the habits of people living in these endemic areas. The awareness of the population is of fundamental importance for this process, the public power must be responsible for this purpose, which should make investments in basic and environmental sanitation, take care of the focus of infection, and thus improve the quality of life of the underprivileged population.

It is necessary to have a control of the transmission, providing an alert for the manifestation of the disease. For in most of the municipalities under study they have a precarious education, and basic sanitation practically nonexistent, being a reality that continues to this day.

\section{REFERENCES}

Barbosa, C.S.; Barbosa, F.S. 1998. Padrão epidemiológico da esquistossomose em comunidade de pequenos produtores rurais de Pernambuco, Brasil. Cad. Saúde Pública, Rio de Janeiro, v.14, n. 1, p. 129-137.

Brazil, Ministério da Saúde. 2010. Secretaria de Vigilância em Saúde. Vigilância e controle da esquistossomose: diretrizes técnicas. Brasília: Ministério da Saúde.

Brazil, Ministério da Saúde. 2011. Sistema Nacional de Vigilância em Saúde: Relatório de Situação: Maranhão. 5. ed. Brasília: Ministério da Saúde. Secretaria de Vigilância em Saúde.

Brazil, Ministério da Saúde. 2014. Vigilância da esquistossomose mansoni: diretrizes técnicas. 4. ed. Brasília. 
Cantanhede, S.P.D.; Fernandez, M.A.; Mattos, A.C.; Montresor, L.C.; Silva-Souza, N.; Thiengo, S.C. 2014. Freshwater gastropods of the Baixada Maranhense Microregion, an endemic area for schistosomiasis in the State of Maranhão, Brazil: I - qualitative study. Revista da Sociedade Brasileira de Medicina Tropical, v. 47, n. 1, p. 79-85.

Couto, J.L.A. 2005. Esquistossomose mansoni em duas mesorregiões do Estado de Alagoas. Rev Soc Bras Med Trop., v. 38, n. 4, p. 301304.

Ferreira, L.A.; Lima, F.L.; Anjos, M.R.; Costa, J.M.L. 1998. Forma tumoral encefálica esquistossomótica: apresentação de um caso tratado cirurgicamente. Revista da Sociedade Brasileira de Medicina Tropical, v. 31, n. 1. P. 89-93.

IBGE - Instituto Brasileiro de Geografia e Estatística. 2016. http://cidades.ibge.gov.br. Acesso em: 01/05/2017.

Nascimento, A.I.P. 2011. Análise Epidemiológica da Esquistossomose em Áreas de Riscos em São Luís - MA. Dissertação de Mestrado. 112p.

Rocha, T.J.M.; Santos, M.C.S.; Lima, M.V.M.; Calheiros, C.M.L.; Wanderley, F.S. 2016. Aspectos epidemiológicos e distribuição dos casos de infecção pelo Schistosoma mansoni em municípios do Estado de Alagoas, Brasil. Rev Pan-Amaz Saude, v. 2, n. 7, p. 27-32.

WHO - World Health Organization. 2011. Schistosomiasis: number of people treated worldwide in 2009. Wkly Epidemiol Rec., v. 9, n. 86, p. $73-80$. 